\title{
Sparking a Worldwide Conversation on School Libraries 2.0
}

\author{
Marlene Asselin, PhD \\ Associate Professor \\ University of British Columbia \\ Canada \\ Ray Doiron, $\mathrm{PhD}$ \\ Professor \\ University of Prince Edward Island \\ Canada
}

\begin{abstract}
The guest co-editors of the School Libraries Worldwide special topic issue on New Learners, New Literacies and New Libraries provide a summary of the key goals of the issue and the worldwide conversation they hope to spark by sharing a diverse set of articles and online resources. Details are provided on developing the journal issue as an open source, online resource; the call for proposals; and the subsequent review process for the issue. The editors provide a further synthesis of key points suggested throughout the review process and the subsequent "publication" of the issue. Questions are raised about reluctance from the field to accept the notion of new learners and new literacies and a tactic claim that these issues are already being addressed in school libraries. The challenge is given for the readers/viewers of this special issue to get engaged in the conversation by responding at the SLW Blog.
\end{abstract}

School Library 2.0

\section{Background}

Since the last IASL conference in 2007, no topic has dominated the school library literature more than the impact of Web 2.0 and the increasing demands for digital literacies for all learners. Evidence has emerged that today's learners think, work, play and create in ways different from their teachers and parents with a seamless integration of a wide variety of digital technologies into their in-school and out-of-school lives (Asselin \& Doiron, 2007). These "new learners' are entering our schools and school libraries in growing numbers and teacher-librarians are seeking ways to transform school libraries into effective and engaging digital learning environments.

As Guest Editors for the July 2008 edition of School Libraries Worldwide, we wanted to explore some of the current research and emerging notions of School Libraries 2.0. By this we mean implications for libraries of Web 2.0, or "the trend in the use of World Wide Web technology, social software and web design that aims to enhance creativity, information sharing, and, most notably, collaboration among users"(Wikipedia). Library 2.0 entails "both physical and mindset changes that are occurring within libraries to make our spaces and services more user-centric and inviting" (Wikipedia). 
As more and more educators face the impact of Web 2.0 and as we see emerging what could be called a Learning or Pedagogy 2.0 environment, it becomes urgent to expand school library pre-service training and in-service professional development to meet the literacy and learning needs of the Net Generation (e.g. Oblinger \& Oblinger, 2005). Fortunately discussions and resources about this challenge are rapidly appearing, many appropriately within Web 2.0 environments (e.g. Classroom 2.0, iBrary, School Library Learning 2.0, and Library 2.0,). A common issue arising across these communities is the need to critically question long held tenets of school libraries and create a new research-based vision that will accord with the current economic and social directions driving educational change (e.g. Partnership for $21^{\text {st }}$ Century Learning, 2007; Government of Canada, 2002).

While the influences of Web 2.0 may vary in regions around the world, there can be little doubt that the challenges raised by new technologies must be addressed by the entire school library community. Without facing the new realities of how many people use information and communication or digital learning technologies, we risk a real danger of becoming isolated as print-only learning environments. We need to draw on our traditional leadership in building collaborative teaching and learning activities in order to engage students in new learning environments which harness their innate interests in new technologies and connect their in-school and out-of-school literacy practices. To begin the process of creating a new vision for the international school library community, we posted a call for papers on the IASL website in August 2007 for a special issue entitled New Learners, New Literacies, New Libraries. The call is reproduced below.

\section{Call for Manuscripts}

Effective teaching today must reflect expanding concepts of literacy that encompass the diverse backgrounds of today's students and the new technologies of information and communication. Given the information-rich world in which "Millennial" live, work and play, how can school library programs and classroom reading programs work together to support traditional instructional goals such as a love of reading and learning the disciplines, and new literacy goals such as proficiency in accessing and evaluating Internet-based information? This themed issue introduces the "new" learners of this Net Generation; explores what literacy means in their global, networked lives, and suggests some practical strategies to help students not only become adept users of technology, but more importantly, ethically and socially responsible information users and knowledge creators.

Three questions form the framework for this themed issue:

1) Who are the learners of the Net Generation?

Evidence suggests that those young people born after 1985 have a distinctive personal identity and a multi-modal approach to learning that differ from their parents and teachers. Their skills in embracing new technologies and their multitasking, multi-modal learning abilities are combining with their global social consciousness and desire to work in socially networked contexts to create a unique challenge for schools and school libraries where traditional approaches to teaching/learning dominate.

2) What are the literacies these learners will need to achieve success in the information-rich, global world in which we live?

The one stable feature of literacy across time and place is that it is constantly evolving. What counted as literacy a generation ago has changed dramatically and will 
continue to change even faster as technology advances and new technologies emerge. Grounded in the pervasive role of critical literacy, we explore the multiple literacies which are influencing the teaching/learning environment created in school libraries.

3) How can school libraries respond to these 'new' learners and play a significant role in developing these 'new' literacies?

School libraries are in a period of significant transformation. New emphasis is being placed on our traditional roles in promoting and developing a love for reading; new technologies are forcing us to explore new ways of providing resources, connecting to the classroom curriculum and teaching information literacy; and our learners are expecting inschool literacy experiences to capitalize on the out-of-school literacies and experiences they are having. What then are some examples of how school libraries are meeting these new challenges?

\section{Developing the Content and the Mode of Publication}

We anticipated great interest in this theme and were surprised at the few inquiries (two) and submissions (two) we received by December (deadline was January 12008 ). During the fall of 2007, we sent the call directly to some people whose work we knew would inform our topic. These people would not normally contribute to school library publications as their work is situated in other areas of educational research We also encouraged those with whom we communicated not to feel restricted to writing traditional research reports, but to use multimedia tools. We envisioned the contents of this issue of School Libraries Worldwide (and the structure of the journal blog) as consisting of three main sections - (1) providing overviews of critical concepts underlying new libraries; (2) describing diverse contexts in which these theories are or could be situated; and (3) a section on creative expressions that illustrate key ideas with Web 2.0 tools. In addition, we encouraged potential authors to contribute shorter than normal pieces in order to highlight current and emerging issues rather than reporting research - although we welcomed both. Finally, we encouraged graduate students in teacher librarianship to compose expressions of what they are learning about the changing school library.

We negotiated with IASL Executive Director, Karen Bonanno, and School Libraries Worldwide Editor, Dr. Dianne Oberg, that this issue would "walk the talk" and be an online, open-access publication. We published this issue in blog and wiki formats as a demonstration of new ways to publish/share information and to allow viewers/readers to add their responses and comments to the content presented. Thus this issue of School Libraries Worldwide was our attempt to create a living example of socially constructing knowledge with Web 2.0 tools.

In the end, we gathered an eclectic set of articles all of which are linked to a variety of web-based resources which support and extend the content in the articles. The authors have varied perspectives and experiences and present a wide variety of issues related to the challenges facing all educators, but in particular, the worldwide school library community. Our idea was to present this core set of articles for all to share and then have readers/viewers explore beyond that core in order to build their own understanding of Web 2.0 and hopefully contribute to the conversation by posting comments at the blog for this issue. In this way, we can explore together the phenomena of social software and Web 2.0 and the influence it continues to have on emerging notions of new school libraries (what some are calling school libraries 2.0). 


\section{Points Drawn from the Process}

As reviews of the manuscripts came back to us, we were again surprised at what they told us about the need for a community conversation about school libraries in the $21^{\text {st }}$ century. We had naively assumed that reviewers, being mostly academics, would be in agreement about the need for drastic change in school libraries in response to changes in literacy, who the learners are, and changes in technology, particularly Web 2.0. However, there was as much variation in views within the academics of the school library community as there are among any other groups. We have synthesized a few key points from our involvement in this process as Guest Co-Editors which for us raise serious questions about our own capacity to respond to the current situation and truly move school libraries forward.

We were struck by how often reviewers felt that the articles they received were really just talking about things we already do in school libraries and that we need to basically continue to focus on information literacy and our traditional core teaching goals. While we would agree that critical thinking/literacy have always been parts of what we do in school libraries, that aspect of our work is even more of a priority and more dominant in what and how we teach. For us, this is evident in the way our students (or as we referred to them throughout the issue - new learners) are experiencing technologies in very different ways and yet, when they come to school, they are not being taught essential critical literacy skills in the depth and frequency with which they must be addressed. So while we claim to be addressing the issues of critical thinking/literacy, we must also recognize that these areas are changing in terms of importance and applications within an ever-increasing digital context. This is not simply a matter of advocating for a larger role for school libraries in building information literacy, but a call for a fundamental shift in our understanding of the pervasive nature of technology and how we must arm our students with a wider range of technical and critical skills in order to cope and flourish in this new learning landscape. We cannot think of this as simply part of our usual collaborative resource-based learning process developed with classroom teachers, but as a more inclusive and comprehensive school-wide, even global approach to learning and teaching with new technologies.

In a related second point, we sensed some resistance to the notion of "new learners', the Millennial or the Net Generation, as being much different from past learners. While we would be quick to agree that in some parts of the world access to computers and other new technologies may not be as pervasive, there can be little doubt that for many of us the children and youth who land in our schools and school libraries today have been deeply influenced by technologies; in many ways these new technologies are the interface between them, their learning and their daily lives. Certainly, new learners have much to learn about the effective, ethical and creative uses of technologies for living and learning in today's world and that is where we in school libraries can call upon our traditional leadership roles. We can first of all recognize and respect their relationship with technology and along with them embrace their new learning experiences/expectations. We can respond to new understandings of how knowledge is constructed in a global learning context and become learners along with them.

Part of the resistance to the notion of any real change needed in school libraries that we observed from reviewers may arise from the tendency to narrowly define the major role of school libraries as being information literacy, when in fact there are multiple literacies and multi-modal uses of literacies expected of learners today. Yes, school libraries have traditionally included critical literacy and visual/media literacy as part of their programs as 
well, but it has been information literacy that has emerged as the major raison d'être. If the readers/viewers can take anything from this issue of $S L W$, we hope it is a growing sense that there are many "new literacies" which our children and youth will need to develop if they are to be fully literate. Navigating digital landscapes, writing in hypertext, using multimodal tools to represent and share new knowledge and engaging in global communication and learning environments call on a wide range of technical competencies, social and cultural values, traditional and new literacies, as well as a commitment to social justice and equity. Our research would suggest that many of our youth are trying to co-exist and function within this world in their out-of-school experiences; it is schools that have narrowed the definition of literacy and school libraries that have narrowed it to information literacy that may be failing to help our youth thrive in the future.

Many of us share a common frustration as we grapple with these challenges. No one seems to have yet shown a model for new school libraries, one we can point to and say "here is an example of a school library 2.0 in action." Certainly as Guest Co-Editors we have not succeeded in doing that either. However, some of the articles and many of the resources we link to at the $\underline{S L W}$ Blog do help us construct some notion of what a 'new' school library may look like. It gives us reason to ask have we as a field been mistaken in trying to describe one vision for a school library and then setting out to create replicas of that vision around the world. Most of us who have worked in frontline school libraries know that no two libraries are exactly alike and maybe this is closer to the idea of school library 2.0 - a school library is uniquely created by its users, from the resources at hand and at a distance which can be called upon to support the construction of new knowledge by the active users of that library. It is a holistic vision of a virtual and a physical space, accessible 24/7 and housing the learning tools needed for a wide range of teaching and learning experiences. It is an open source, open access environment, a social space where users gather virtually and physically to find multiple types of resources and create strongly visual, multimedia representations of their new understandings. We need only to look to our colleagues in academic libraries who are busy converting their libraries to be a "learning commons" where the social gathering traditions of libraries are blended with social learning contexts.

As Guest Co-editors this was most clearly evident in the visioning of school library 2.0 developed by Sharon Doyle and Lilian Trousdell. Their School Library Mash-Up is just that, a multimedia mashing of images, music, and ideas into a vision of what a school library of the future is like. In no time has the adage "the medium is the message" ever been truer that in these times where our youth (and hundreds of commercial enterprises) are combining multiple forms of texts into new multi-layered "texts" which challenge our traditional views of how new knowledge is constructed and shared. Another example is provided by Maryam Moayeri in her Interviews with Young People where she lets the voices of youth and current teacher-librarians speak about what a school library should be like. Are these examples of the products of research/learning that our students should be developing? While many would still hold to the notion that the traditional research essay is still a fundamental skill all students need, we risk the danger that school libraries will be ignored by learners as they press on with both a socially constructed sense of knowledge-building and a compulsion to share their ideas, opinions and understandings with their peers and the world.

One reviewer took particular aim at this form of "knowledge-building" as more or less a cutting and pasting activity with no new understanding being reached beyond the social realm. We would challenge this and say that not only do these products demonstrate the new learner applying a full range of new literacies to create and distribute new knowledge, they 
really represent the cutting edge of whole new ways of understanding how knowledge and understanding will be built in the future.

\section{A Final Thought}

Our hope is that the readers/viewers of the July 2008 issue of School Libraries Worldwide will welcome this issue as part of a larger conversation that is happening in the literacy world and that must become priority in the school library community. You need to get engaged in this conversation and hopefully you will add your comments and feedback to the articles and resources provided at the SLW Blog. Another adage that has become embedded in our cultures is that we need to "Think globally and act locally"; we would challenge that concept and suggest in the school library context we need to "Think locally but act globally" and create a global vision of one Worldwide School Library that is guided by principles of equity, inclusion, and social justice, where our local libraries are nodes in this worldwide network and our students connect within and throughout that network as global learners. Perhaps this is what school libraries 2.0 could become. 


\section{References}

Asselin, M., \& Doiron, R. (2007). Literacy, libraries and learning. A presentation at the University of Zurich, Zurich Switzerland, April 2007.

Government of Canada. (2002). Knowledge matters: Skills and learning for Canadians. Retrieved May 6, 2008 from http://www11.sdc.gc.ca/sl-ca/home.shtml

Oblinger, D., \& Oblinger, J. (Eds.). (2005). Educating the net generation. Retrieved July 6, 2007, from http://www.educause.edu/educatingthenthegen

Partnership for $21^{\text {st }}$ Century Learning Skills (2007). Retrieved April 20 2008, from http://www.21 centuryskills.org/index.php?option=com content\&task=view\&id=254\&Itemid $=120$

O’Reilly, T. (2005). What is Web 2.0? Accessed May 20, 2008, from: http://www.oreillynet.com/pub/a/oreilly/ tim/news/2005/09/30/what-is-web-20.html

\section{Biographical Notes}

Marlene Asselin, PhD is Associate Professor in the Department of Language and Literacy Education at the University of British Columbia. She has research programs in literacy education, information literacy, and school librarianship, and has established a component of Teacher Education that focuses on information literacy. You may contact her at mailto:marlene.asselin@ubc.ca

Ray Doiron, PhD is a professor in the Faculty of Education at the University of Prince Edward Island, Canada. He teaches courses in early literacy methods, children's literature and the role of the school library. He has recently completed research on an early literacy nutrition program and is currently engage din research on social networking. Ray is a frequent conference speaker on the connection between literacy and libraries, and he has developed several e-learning applications of social networks, wikis and blogs. You may contact him at raydoiron@upei.ca

\section{Statement of Originality}

This statement certifies that the paper above is based upon original research undertaken by the author and that the paper was conceived and written by the author(s) alone and has not been published elsewhere. All information and ideas from others is referenced. 